\title{
The Hidden Benefits of Pollinator Diversity for the Rangelands of the Great Plains: Western Prairie Fringed Orchids as a Case Study
}

\section{By Steven E. Travers, Gerald M. Fauske, Kristina Fox, Andrew A. Ross, and Marion O. Harris}

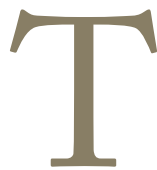
he richest and most productive plant communities, including the grasslands typical of the Great Plains, are complex associations of different spe-

cies dependent on the environment (nutrients and water), as well as ecological connections or relationships with other species. In particular, the mutual benefits of plantpollinator relationships increase plant reproduction and population growth, increase genetic diversity of individual species, and allow more species to coexist in a plant community, all of which makes a prairie a prairie rather than an admixture of weeds. The diversity of plant species in a grassland is of more than passing interest to rangeland managers because there are clear management benefits to diversity, including increased forage production for livestock and wildlife grazing, improved soil structure, and community resilience to environmental disturbances. Yet, it is easy to overlook the complexity and diversity of pollination relationships of native prairie plants when evaluating long-term management options. Here we argue that the diversity of native grasslands depends on a diversity of pollinators. As a case study, we discuss the complex ecological interactions of pollinators, the Western Prairie Fringed Orchid (Platanthera praeclara), and other native prairie species. Our goal is to answer the following questions: How does pollination play a role in the maintenance of rare plant species? How do pollinators other than bees benefit grassland plant communities? And, how do these other pollinators differ from bee pollinators?

\section{How Does Pollination Play a Role in the Maintenance of Rare Plant Species?}

The sexual reproduction made possible by pollination increases genetic variation in offspring, with this then allowing for greater evolutionary potential. In plants there are many ways to reproduce. One is "tillering," or asexual reproduction, which produces another individual that is genetically identical to the parent (e.g., ramets produced from stolons or rhizomes). Another is "selfing," where pollen and ovules combine and produce a zygote, but both are from the same plant. Both of these mechanisms of producing a new generation of plants have problems associated with them. The biggest is that asexual reproduction and selfing yield little new genetic variation in the next generation of plants. Breeders of crops and livestock long ago revealed that the potential for new beneficial traits in new varieties depended directly on the amount of genetic variation in the population from which they were selecting. In the same way, genetic variation in future generations of native plants is beneficial because it translates into trait diversity, adaptability, and resilience of populations. Populations with these characteristics have an increased chance of surviving in changing environments. ${ }^{1}$

Outcross pollination is different and has several important benefits. Outcross pollination, where an animal (e.g., insect or bird) or the wind brings pollen from one individual to another, can create brand new combinations of genes in the seeds of the next generation. Pollination can combine genes from different populations adapted to very different local environments and create greater diversity within the gene pools of a species. Another benefit of outcross pollination is the masking or hiding of detrimental traits. Many genetic deficiencies in plants and animals that ultimately can lead to reduced performance or lethality are the product of recessive alleles that cause the most trouble when in the homozygous condition. Selfing and pollination between 
closely related individuals (inbreeding) increases the occurrence of this homozygous condition where there are two recessive alleles instead of just one. Inbred and excessively selfed plants that have not been outcross-pollinated often are less robust than other plants.

Some plant species have evolved exclusive relationships with specific pollinators and are incapable of any other means of reproducing. These species go extinct if their pollinator disappears. These kinds of relationships link the biodiversity of a plant community with the biodiversity of overlapping animal communities. On the other hand, communities of plants as a whole benefit synergistically from the mutualistic relationships of their individual species. Pollinators generally benefit from pollinating plants by receiving rewards from the plants, including energy-rich nectar or the pollen itself. In the presence of generalist pollinators, a greater selection of plant species from which to choose can increase visitation to a patch (although more individual plants can increase competition). Multiple plant species in a community all can benefit by the presence of other plants attracting pollinators regionally because this can increase their level of pollinator visitation. By rewarding and attracting pollinators as a group, individual species can receive more pollinator service than each could on its own.

A rich native plant community is a mixture of species that range from common to rare. Rare plants often benefit the most from outcross pollination because they are at greater risk for the genetic problems associated with selfing and inbreeding. First, inbreeding and selfing are more likely in small populations or low-density populations visited by pollinators that move relatively short distances. In rare plants the most likely mates are nearby, and therefore are closely related if they came from the same maternal plant. Small populations also can translate into small gene pools with little genetic diversity. Allee effects refer to the observed pattern that there often is a positive correlation between population density and population growth rate. In plants, this relationship can be related to decreased pollinator visitation to small and low-density patches of individuals. Smaller populations are less likely to attract pollinators due to the relatively small amount of reward provided and because they are simply harder for pollinators to find. ${ }^{2}$ Finally, all of these problems linked to reduced genetic diversity are greatly magnified in populations of rare plants. Reduced hardiness and adaptability translate into reduced recruitment, leading to a feedback loop that ends in extinction. ${ }^{3}$ When rare plants disappear, plant communities and pollinator communities move towards monoculture and the loss of important ecological services such as improved forage quality and resilience for livestock and wildlife habitat.

\section{A Prairie Ghost}

Perhaps the best example of a rare grasslands species that relies on pollinators other than bees is the Western Prairie Fringed Orchid (hereafter WPFO). This fringed orchid is

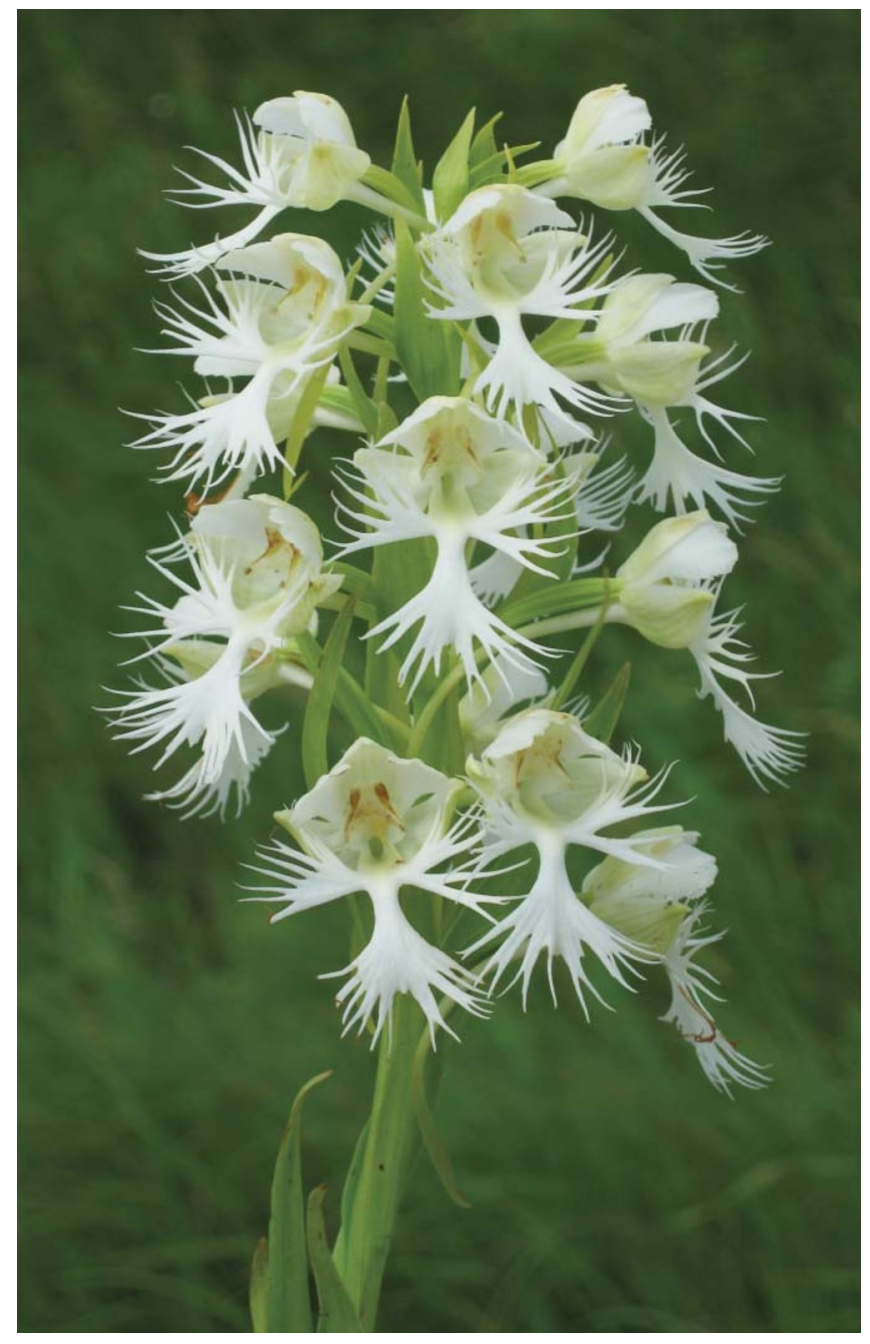

Figure 1. Western Prairie Fringed Orchid (Platanthera praeclara) flowering stalk. This species has one of the longest nectar spurs $(50 \mathrm{~mm})$ of any North American plant.

unique in its genus because its range reaches well into the tallgrass prairie habitats typical of the subhumid areas of the Great Plains. Other Platanthera species typically are found in more wooded areas in the eastern part of the continent. The flowering stalks of this enigmatic ghost can reach $1 \mathrm{~m}$ in height and hold sprays of up to 20 pure white flowers that are each 2 inches across (Fig. 1).

The WPFO is a symbol of the vanishing tallgrass prairie. As this type of prairie has been converted to cropland, this orchid has decreased dramatically in abundance. The plants that have been studied the most are found in three metapopulations that are located in the Red River Valley, one in southeastern North Dakota at the Sheyenne National Grassland and the Nature Conservancy's Brown Ranch, the second in northwestern Minnesota on state and Nature Conservancy land, and the third in southern Manitoba at the Manitoba Tall Grass Prairie Reserve. Much less is known about the smaller WPFO populations that occur on public and private lands in Iowa, Missouri, Nebraska, and 


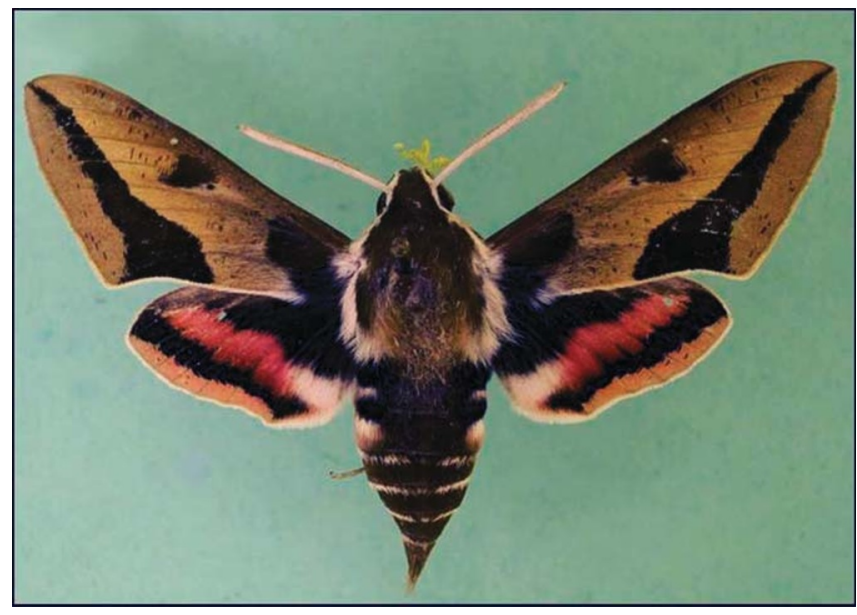

Figure 2. Hawkmoth pollinator of fringed orchids and other native prairie plants. Note the finger-like orchid pollinia attached to this moth's head. The biodiversity of grasslands is dependent on non-Apoidea (bee) pollinators such as this.

Kansas. However, preliminary genetic data suggests that small isolated populations share only a few of the same genes as other larger populations and might be diverging evolutionarily (A. A. Ross, unpublished data, 2010). In the United States, the WPFO was listed as a threatened species in 1989 under the Endangered Species Act of 1973. In Canada, it was listed as endangered in 2003 under the federal Species at Risk Act. The WPFO illustrates the importance of diversity for managing populations of rare plant species. Its presence in the Great Plains represents an important contribution to prairie biodiversity.

The orchid is not pollinated by the typical pollinator (i.e., bees). Instead pollinators are hawkmoths of the Family Sphingidae, 4,5 a family of large, mostly crepuscular moths (Fig. 2) capable of flying long distances. Hawkmoths search for nectar sources by integrating sensory information from olfactory and visual systems. ${ }^{6}$ The WPFO is highly apparent to these sensory systems because of its large inflorescence and showy white flowers and because of a strong fragrance, which is produced starting at dusk (when hawkmoths begin to fly) and through the night. The reward for visiting the orchid is nectar: on average, each flower of the inflorescence contains $13 \mu \mathrm{L}$ of nectar. However, because nectar typically only is found in the bottom $18 \mathrm{~mm}$ of the $50-\mathrm{mm}$-long narrow nectar spur, short-tongued pollinators (such as bees) usually cannot access the nectar via the opening of the nectar spur. In contrast, hawkmoth pollinators have a tongue that ranges in length from $28-40 \mathrm{~mm}$. While using the tongue to search flowers for nectar, the moth places its head within the teacup-shaped flower. Here, if the head of the moth has the proper dimensions, the compound eyes contact one or both of the sticky pads (viscidia) that connect to the orchid's pollinia, the paired structures that encase the pollen. When leaving the flower, the moth removes the pollinium, which now takes up a position in front of the moth's head. This is an ideal position for pollinating flowers that are visited subsequently. Such floral visits might be to a flower within the same inflorescence or the flower of a nearby or distant orchid, the latter being possible because hawkmoths fly long distances. Flight occurs during migration and also during the male's search for mates (via tracking of a femaleproduced sex pheromone) and during the female's search for larval host plants (via orientation to plant visual and chemical cues). The amount of nectar provided by each flower is enormous compared to other prairie flowers and is an important resource for supporting the presence of hawkmoths in the prairie. Nectar is a critical fuel for hawkmoth flight and also provides resources for the female to mature additional eggs. ${ }^{7}$

Unlike some tropical orchids that have a single hawkmoth pollinator, the WPFO appears to recruit whatever hawkmoth species are present in the area. In the Sheyenne National Grassland in southeastern North Dakota, five hawkmoth species have been found carrying WPFO pollinia on their compound eyes and are assumed to be pollinators: Achemon sphinx (Eumorpha achemon), wild cherry sphinx (Sphinx drupiferarum), ${ }^{4}$ spurge hawkmoth (Hyles euphorbiae), ${ }^{8}$ white-lined sphinx $(H$. lineata), and hermit sphinx (Lintneria eremitus). ${ }^{5}$ The most obvious case of recruiting any hawkmoth (rather than specializing in recruiting a single species) is the spurge hawkmoth, a European species that was brought to North America 40-50 years ago as a biological control agent for the noxious weed leafy spurge. After its introduction, it was not established in North Dakota until 1998 when numbers of larvae could be found on leafy spurge in western North Dakota. Five years later it was found in southeastern North Dakota (which has plenty of leafy spurge) carrying WPFO pollinia. ${ }^{8}$ It is now by far the most abundant of the five hawkmoth species and might be the most important pollinator for this orchid metapopulation. This "rescue" of the orchid was timely because several of its pollinators appear to be rare. For example, the white-lined sphinx $(H$. lineata $)$, is a migrant from the south and rarely shows up in the Sheyenne Grassland ( 2 of 8 years). The two remaining pollinator species, the hermit sphinx and the wild cherry sphinx, are rare each year, and in some years are not found at all. ${ }^{5}$

Maintaining the orchid's pollinators in the grasslands requires more than just the orchid. Most importantly, each hawkmoth species requires host plants for larvae. The search for host plant is presumably what keeps the female moth flying in a particular area, with visits to orchids then fueling that flight. The host plants of the five hawkmoth pollinators consist of a diverse set of species, ranging from mints to cherry trees. A second requirement for keeping hawkmoths in areas where orchids grow is the presence of plants that provide nectar during the periods before and after orchid flowering. This especially is important for the newly recruited pollinator, the spurge hawkmoth, which appears to have two generations each year. Adults of the first generation start flying in May or early June (before the orchid flowers) and 
Table 1. List of plant species flowering coincidentally with Western Prairie Fringed Orchids in western Minnesota. Lepidopteran pollinators have been observed visiting all of these species. Data compiled from Dunnell ${ }^{9}$

\begin{tabular}{|c|c|}
\hline Scientific name & Common name \\
\hline Achillea millefolium & Yarrow \\
\hline Agoseris glauca & False dandelion \\
\hline Allium stellatum & Prairie onion \\
\hline Amorpha canescens & Lead plant \\
\hline Amorpha fruticosa & False indigo \\
\hline Anemone canadensis & Canadian anemone \\
\hline Anemone cylindrica & Candle anemone \\
\hline Apocynum cannabinum & Indian hemp \\
\hline Aquilegia canadensis & Red Columbine \\
\hline Asclepias ovalifolia & Ovalleaf milkweed \\
\hline Asclepias syriaca & Common milkweed \\
\hline Calylophus serrulatus & Yellow evening primrose \\
\hline Campanula rotundifolia & Harebell \\
\hline Castilleja sessiliflora & Downy paintbrush \\
\hline Castilleja sulphurea & Yellow painted cup \\
\hline Cicuta maculata & Water hemlock \\
\hline Conringia orientalis & Hare's ear mustard \\
\hline Cypripedium parviflorum & Yellow ladyslipper \\
\hline Dalea candida & White prairie clover \\
\hline Dalea purpurea & Purple prairie clover \\
\hline Delphinium carolinianum & Prairie larkspur \\
\hline Desmodium canadense & Showy tick-trefoil \\
\hline Echinacea angustifolia & Purple coneflower \\
\hline Erigeron philadelphicus & Philadelphia fleabane \\
\hline Gaillardia aristata & Blanket flower \\
\hline Galium boreale & Northern bedstraw \\
\hline Gaura coccinea & Scarlet gaura \\
\hline Heterotheca villosa & Golden aster \\
\hline Heuchera richardsonii & Alum root \\
\hline Liatris aspera & Tall blazing star \\
\hline Liatris pycnostachya & Prairie blazing star \\
\hline Lilium philadelphicum & Wood lily \\
\hline Lobelia spicata & Pale-spike lobelia \\
\hline Melilotus officinalis & White sweet clover \\
\hline
\end{tabular}

\section{Table 1. Continued}

\begin{tabular}{|c|c|}
\hline Monarda fistulosa & Wild bergamot \\
\hline Oenothera nuttallii & White evening primrose \\
\hline Oenothera serrulata & $\begin{array}{l}\text { Toothed-leaved evening } \\
\text { primrose }\end{array}$ \\
\hline Onosmodium occidentale & False gromwell \\
\hline Osmorhiza claytoni & Sweet cicely \\
\hline Packera plattensis & Prairie groundsel \\
\hline Panicum virgatum & Switchgrass \\
\hline Pediomelum esculentum & Large indian breadroot \\
\hline Penstemon gracilis & Lilac flowered penstemon \\
\hline Penstemon grandiflorus & Large beardtongue \\
\hline Pentemon albidus & White penstemon \\
\hline Physalis virginiana & Ground cherry \\
\hline Potentilla arguta & Tall cinquefoil \\
\hline Potentilla pensylvanica & Pennsylvanica cinquefoil \\
\hline Prunella vulgaris & Self-heal \\
\hline Psoralea argophylla & Silverleaf scurfpea \\
\hline Pycnanthemum virginianum & Virginia mountain mint \\
\hline Ratibida columnifera & Prairie cone flower \\
\hline Rosa arkansana & Wild prairie rose \\
\hline Rudbeckia hirta & Black-eyed susan \\
\hline Symphyotrichum falcatum & White prairie aster \\
\hline Thalictrum dasycarpum & Tall meadowrue \\
\hline Thalictrum dioicum & Early meadowrue \\
\hline Tradescantia occidentalis & Spiderwort \\
\hline Tragopogon dubius & Goatsbeard \\
\hline Verbena stricta & Hoary vervain \\
\hline Vicia americana & Wild vetch \\
\hline Zigadenus elegans & White camas \\
\hline
\end{tabular}

continue flying into early July (when the orchid starts flowering). The second generation starts flying in the second half of July into August and pollinates the orchid during the final weeks of flowering. In the years when the white-line sphinx shows up, it also needs nectar plants before and after the orchid flowers.

In turn, these other nectar plants visited by the orchid's pollinators benefit through the outcrossing that is provided. In a study of native prairie plants flowering at the same time and place as WPFO populations in western Minnesota (Table 1), there were 35 species identified that were possible 
nectar sources and outcrossing beneficiaries from hawkmoth visitation. ${ }^{9}$ In the absence of these additional plant species, orchids would be visited less often if the pollinators on which they are so dependent did not have enough to eat and moved on to other places. Rare plants such as the orchid promote diversity of grasslands by supporting pollinators of other plants. They also benefit from a diverse plant community that supports a diverse pollinator community.

A final point is that the orchid provides nectar to other threatened prairie pollinators. A significant proportion of plants $(40 \%)$ and flowers (10\%) are robbed via cuts into the side of the nectar spur (K. Fox, unpublished data, 2008). Fortunately, nectar robbery does not appear to have negative effects for reproduction of the flower or the plant. The robbers appear to be bumblebees, which are important pollinators of other prairie plants, as well as being threatened species of the grasslands. This is an additional ecological service provided by the orchid, and another example of the complex web of relationships that exist between and among prairie plants and prairie insects.

\section{Pollination Services Without Bees}

Despite bees receiving the lion's share of attention in regard to pollination of native plants, there are many other insect pollinators that play an arguably more important role in the grasslands of North America. Lepidopteran pollinators (moths and butterflies) are unique in three important ways. First, one species or another is active 24 hours/7 days a week throughout the growing season. Pollinators of other insect orders, including bees and wasps, are virtually all diurnal in their pollinator activities. Within the Lepidoptera, butterflies are diurnal, hawkmoths are mostly crepuscular (active at dusk and dawn), a few are diurnal, some are nocturnal, and a few are matinal (active during pre-dawn). Owlet moths and crambid moths, although mostly nocturnal, also have species active at other times in the 24-hour cycle. Many micro-Lepidoptera are avid diurnal flower visitors as well.

Second, Lepidoptera uniquely transport pollen across a range of distances, including short, intermediate, and very long distances. In general, there is a correlation between body size and distances traveled; micro-Lepidoptera are local, whereas hawkmoths sometimes travel more than a thousand miles. Thus, hawkmoths, whose host plants are native to the Gulf States, might be flitting from flower to flower in the northern Great Plains by the end of the growing season. In contrast, sedge moths or fairy moths only can be local floral visitors. The dispersal abilities of Lepidoptera give plants "options" of local or distant pollination. This means that wide-ranging plants have at their disposal wideranging pollinators. Butterflies are known both for their long-distance migrations (monarch) but also for their annual long distance immigrations (painted lady, red admiral). Similarly many common owlet moths move northward with the season (black cutworm, armyworm, corn earworm) and one species (army cutworm) has seasonal migrations from the Great Plains to the Rocky Mountains and back each growing season. The movement of Lepidoptera differs fundamentally from that of bees (which operate locally from a central "base," be it a solitary nest or a communal hive), or flies (which often are seen to work one floral patch), or beetles (which often extensively work the blossoms of a single plant).

Finally, after tallying numbers of species in groups that are predominately floral visitors, we find that there are nearly 4,500 Lepidoptera that are regular floral visitors in North America. By comparison, there are 3,700 Hymenoptera (bees, wasps, ants, etc., that are regular floral visitors [of which 3,500 are bees]), at least 2,000 Coleoptera (beetles), and 1,700 Diptera (flies). This makes the Lepidoptera the largest group of potential pollinator species and shows that the Apoidea (bees) make up only a third of potential plant pollinators (Table 2).

The services these pollinators provide in terms of promoting reproduction and out-crossing in native grasslands is crucial to the maintenance of plant biodiversity. Likewise, these pollinators are dependent on diverse plant (and animal) communities to persist. ${ }^{10}$ There are multiple reasons for this interdependence. Excepting most Apoidea (bees), other insect floral visitors usually are dependent on a different host plant (or animal). For example, the asteroid hooded owlet (Cucullia asteroides) has aster as its larval host, but adults visit many flowering plants. The hermit sphinx is dependent on mints (Lamiaceae) as a larva, yet has been recorded as a pollinator of the WPFO. Because of the difference between adult feeding behaviors and larval hosts exhibited by nonbee pollinators, a more diverse plant community is required to support these insects. By contrast, although many bees are polylectic (visiting many flowers) or oligolectic (visiting only one type or few types of flowers), non-bee floral visitors are dependent on flowers not only for adult nutrition, but also for larval development. From a flowering plant's "point of view," living in a diverse habitat with many other flowering plant species triples the numbers of available pollinators. A diverse community then supports a diversity of other insect herbivores not involved in pollination services and their itinerant parasites and predators, not to mention a community of scavengers.

The greater diversity of both plants and insects translates into greater complexity of community structure and a greater overlap of functional roles. What does this mean? First, when more than one species performs a particular functional role (pollination of the Western prairie fringed orchid, for example), the loss or temporary population reduction of a particular pollinator species at one locality will not mean the loss of the pollinated plant at that locality or overall. Likewise, a local extinction of one particular plant might not mean the extinction of its pollinator because it will be able to rely on other plants. That means if the plant is reintroduced, its pollinator will still be present and able to pollinate the restored plant. In other words, the loss of one species will not mean the loss of its functional role in the community. 
Table 2. North American insect taxa which are predominately floral visitors (data compiled from numerous sources; see Sources for Table 2 at the end of this article)

\begin{tabular}{|c|c|c|}
\hline Order, lower taxa (family, subfamily) & Common name & NA species* \\
\hline \multicolumn{3}{|l|}{ Lepidopterat (total $=4,472$ ) } \\
\hline Prodoxidae & Yucca moths & 56 \\
\hline Adelidae & Fairy moths & 18 \\
\hline Glyphipterygidae & Sedge moths & 40 \\
\hline Heliodinidae & Sun moths & 20 \\
\hline Ethmidae & Ethmid moths & 45 \\
\hline Scythrididae & Scythrid moths & 90 \\
\hline Choreutidae & Choreutid moths & 46 \\
\hline Sesiidae & Clearwing moths & 123 \\
\hline Crambidae: Pyraustinae & Pyraustine snout moths & 364 \\
\hline Sphingidae & Hawkmoths & 120 \\
\hline Erebidae & Erebid moths & 400 \\
\hline Noctuidae (sensu stricto) & Owlet moths & 2,350 \\
\hline Papilionoidea & Butterflies & 515 \\
\hline Hesperioidea & Skippers & 285 \\
\hline \multicolumn{3}{|l|}{ Coleoptera (total $=2,007$ ) } \\
\hline Scarabiidae: Cetonini & Flower chafers & 60 \\
\hline Cantharidae & Soldier beetles & 370 \\
\hline Cleridae & Clerid beetles & 291 \\
\hline Melyridae & Soft-winged flower beetles & 520 \\
\hline Phalacridae & Shining flower beetles & 28 \\
\hline Meloidae & Blister beetles & 410 \\
\hline Anthicidae: Antrhicini & Flower beetles & 120 \\
\hline Ceranbycidae: Lepturinae & Flower longhorned beetles & 208 \\
\hline \multicolumn{3}{|l|}{ Diptera (total $=1,700)$} \\
\hline Bombyliidae & Bee flies & 900 \\
\hline Syrphidae & Hover flies & 800 \\
\hline \multicolumn{3}{|l|}{ Hymenoptera (total $=3,700$ ) } \\
\hline Apoidea & True bees & 3,500 \\
\hline Chrysididae & Chrysidid wasps & 200 \\
\hline
\end{tabular}

*Numbers of North American species that have, or likely have floral visiting habits.

tConservative estimates, the feeding habits of many thousands of microlepidoptera are too incompletely known to characterize by family.

\#Many additional species are incidental flower visitors, but habits are too incompletely known to have separate family listings.

Interestingly, the loss (or gain) of a species (plant or animal) from a diverse community can have long-reaching effects that are not immediately apparent. As an example consider the consequences of the spread of an invasive rangeland plant species. Leafy spurge (Euphorbia esula) was introduced into North America. It is an economically important plant in the Sheyenne National Grasslands of southeastern North Dakota because its presence in 
rangeland reduces the amount of forage available in this multi-use environment; cattle feed on both grasses and forbs, but not leafy spurge. In pastures where spurge is abundant, there is increased grazing pressure on the remaining plant community. One of those native plant groups includes mints, some of which are host plants for the hermit sphinx, which in turn is a pollinator of the WPFO. Another example of introductions with complex consequences includes insects that have been introduced into North America to control leafy spurge. Two of the moths are a leaf tier (Lobesia euphorbiana [Freyer]) and the spurge hawkmoth. The larvae of the spurge hawkmonth consumes whole stems of leafy spurge, and the adult moths carry pollinia of the WPFO-an unexpected beneficial outcome. Meanwhile, larvae of $L$. euphorbiana tie the growing tips of leafy spurge. The presence of these moths reduces spurge density and opens areas for cattle grazing. As a consequence, moths increase productivity of a given parcel of rangeland and reduce pressure on the forb community. Increased forb nectar sources, coupled with decreased spurge sources, shifts pollinator activities back to native plants, which also increases rangeland productivity. This in turn, increases survival of pollinators that again drive plant diversitya positive feedback loop.

\section{Conclusions}

A resilient and speciose grassland ecosystem is more than a collection of species. One of the best examples of mutualistic relationships among species, pollination, is a key force in the maintenance and promotion of biodiversity in these ecosystems. Individual plant species and populations reap the benefits of outcrossing and sexual reproduction in the presence of a diversity of pollinators. These benefits translate to higher scales when collections of plant species benefit one another by supporting diverse pollinator communities collectively. In this way there is a positive feedback system where biodiversity begets and supports biodiversity. Moreover, because pollination relationships themselves are diverse from specific to general, the promotion of pollinator species across the taxonomic spectrum from bees to butterflies to beetles is an important part of plant biodiversity and therefore in the best interests of natural resource managers. E.O. Wilson said, "Nature is kept productive and flexible by uncounted thousands of such partnerships."10 Thus, it behooves everyone interested in the productivity and flexibility of grassland communities to never forget the diversity of these partnerships.

\section{References}

1. Westermeier, R., J. Brawn, S. Simpson, T. Esker, R. Jansen, J. Walk, E. Kershner, J. Bouzat, and K. Paige. 1998.
Tracking the long-term decline and recovery of an isolated population. Science 282:1695-1698.

2. McCarthy, M. 1997. The Allee effect, finding mates and theoretical models. Ecological Modeling 103:99-102.

3. Soule, M., And L. S. Mills. 1998. Population genetics-no need to isolate genetics. Science 282:1658-1659.

4. Cuthrell, D. L. 1994. Insects associated with the prairie fringed orchids, Platanthera praeclara Sheviak \& Bowles and P. leucophaea (Nuttall) Lindley [MSc. Thesis]. Fargo, ND, USA: North Dakota State University. 76 p.

5. Fox, K. A. 2008. Hawkmoths (Family Sphingidae) associated with the western prairie fringed orchid in southeastern North Dakota [MSc. Thesis]. Fargo, ND, USA: North Dakota State University. 70 p.

6. Raguso, R. A. 2004. Flowers as sensory billboards: progress towards an integrated understanding of floral advertisement. Current Opinion in Plant Biology 7:434-440.

7. O’Brien, D. M., D. P. Schrag, and C. Martinez del Rio. 2000. Allocation to reproduction in a hawkmoth: a quantitative analysis using stable carbon isotopes. Ecology 81: 2822-2831.

8. Jordan, C. R., G. M. Fauske, M. O. Harris, and D. Lenz. 2006. First record of the spurge hawkmoth as a pollen vector for the western prairie fringed orchid. Prairie Naturalist 38:63-66.

9. Dunnell, K. 2010. Plant phenological responses to climate change in the northern Great Plains. [MS. Thesis]. Fargo, ND, USA: North Dakota State University. 78 p.

10. Buchmann, S., and G. Nabhan. 1996. The forgotten pollinators. Washington, DC, USA: Island Press. 292 p.

\section{Sources for Table 2}

1. Arnett, R. H. Jr., M. C. Thomas, P. E. Skelley and J. H. Frank. 2002. American Beetles. Volume 2. Polyphaga: Scarabaeoidea through Curculionoidea. Washington, DC, USA: CRC Press.

2. McAllpine, J. F. 1981. Manual of Nearctic Diptera. Volume 1. Monograph 27. Ottawa, Ontario, Canada: Research Branch, Agriculture Canada. $674 \mathrm{p}$.

3. Michner, C. D. 2007. The Bees of the World. 2nd Edition. Baltimore, MD, USA: Johns Hopkins University Press.

4. Opler, P. A. and G. O. Krizek. 1984. Butterflies east of the Great Plains. Baltimore, MD, USA: Johns Hopkins University Press.

5. Powell, J. A. And P. A. Opler. 2009. Moths of Western North America. Berkeley, CA, USA: University of California Press.

6. Royer, R. A. 2003. Butterflies of North Dakota. Minot, ND, USA: Minot State University Science Monograph 2.192 p.

7. Tuttle, J. P. 2007. The Hawkmoths of North America. Washington, DC, USA: Wedge Entomological Foundation.

AuthorsareAssistantProfessor, Steven.Travers@ndsu.edu (Travers) and Graduate Student (Ross), Department of Biological Sciences, North Dakota State University, Fargo, ND 58108, USA; Research Specialist (Fauske), Graduate Student (Fox), and Professor (Harris), Department of Entomology, North Dakota State University, Fargo, ND 58108, USA. 